\title{
Carla Rinaldi
}

Fondazione Reggio Children - Centro Loris Malaguzzi (The Reggio Children - Loris Malaguzzi Centre Foundation, Italy) e-mail: carla.rinaldi@unimore.it

ORCID: 0000-0001-9620-5729

DOI: $10.15290 / \mathrm{mhi} .2020 .19 .01 .01$

\section{The child as citizen: holder of rights and competent. The Reggio Emilia educational experience}

\begin{abstract}
The Convention on the Rights of the Child, approved by the General Assembly of the United Nations on 20 November 1989, states in Article 2 that "States Parties shall respect and ensure the rights set forth in the present Convention to each child within their jurisdiction without discrimination of any kind, irrespective of the child's or his or her parent's or legal guardian's race, colour, sex, language, religion, political or other opinion, national, ethnic or social origin, property, disability, birth or other status." Therefore, the child becomes a citizen from birth and is competent to learn from birth. Competent in learning, asking questions, seeking answers, and generating a culture of their own. By affirming the right to be recognised as a citizen of the present, competent, culture-generating, we affirm the strength and extraordinary potential of the child and their right to express it. Infant-toddler centres and preschools are excellent educational places, where to build the paradigm of care and community for the child as citizen. Not all-encompassing places for education, but essential. They help to process, rework and update childhood data, to define childhood and to be defined by them and to define societies. It is not just the care of the child, it is the child's culture, it is the child's look at the world, their generative whys. The great cultural and political "revolution" of the last century never completely accomplished - is making children active protagonists, leaving
\end{abstract}


them their autonomy, considering them as holders of rights and culture. But now we know that society needs its childhood, too.

Key words: child, rights, competent, educational poverty, citizen, Fondazione Reggio Children

\section{The child as citizen: holder of rights and competent}

The Convention on the Rights of the Child, approved by the General Assembly of the United Nations on 20 November 1989, states in Article 2 that "States Parties shall respect and ensure the rights set forth in the present Convention to each child within their jurisdiction without discrimination of any kind, irrespective of the child's or his or her parent's or legal guardian's race, colour, sex, language, religion, political or other opinion, national, ethnic or social origin, property, disability, birth or other status."

The child is holder of rights and a citizen from birth, a citizen of the present, not only of the future and well beyond the limits of country borders. And competent since birth. The definitions that we worked out in the 1970s, have been articulated over time, becoming and symbolizing a paradigm shift, which in part still remains the horizon to look at. The child as citizen from birth therefore not only a private subject, "son, daughter of...", but a citizen - represents a burst upon the scene of a new subject of individual, legal, civil and social rights. However, this is a very recent issue, or achievement, chronologically very recent; in fact, it is only in the nineties of the past century that the international conventions on the rights of child have recognized children's legal subjectivity separate from their parents'. From this perspective, the pedagogy of Reggio Emilia looked at childhood with a sensitivity that has not been expressed in international law yet, and this sensitivity is to be reconfirmed in daily educational practice - in Reggio Emilia, in Italy, and in the world.

By affirming the right to be recognised as a citizen of the present, we affirm and confirm the strength and extraordinary potential of the child and their right to expand and express this potential. Children are "constructors of their own experience and thus active participants in the organization of their identities, abilities, and autonomy, through relationships and interaction with their peers, with adults, with ideas, with objects, and with the real and imaginary events of intercommunicating worlds"1.

$1 \quad$ L. Malaguzzi, A Charter of Rights, 2. 
In fact, each child is credited with "an extraordinary wealth of inborn abilities and potential, strength and creativity. Irreversible suffering and impoverishment of the child is caused when this fact is not acknowledged"2.

The child is the essence of the human being, the young child, so full of abilities in their capacity for research and connections, has the role of being the genetics of the human being, their DNA, their immense potential.

They are the human beings who know how to question themselves and others, be surprised and ask why, change patterns and expectations and, at the same time, innovate. The human being, as a child, is the researcher par excellence. Their nature is characterized by being incredibly provided with abilities. "The child is made of one hundred" says the poem-manifesto by Loris Malaguzzi. One hundred languages, one hundred hands, one hundred thoughts, one hundred ways of thinking and playing, speaking, marveling, loving and understanding. Education has to give voice to these hundred languages and not to play the role of those who steal 99 of them: school and culture, which "separate the head from the body" and tell them to "think without hands, to do without head, to understand without joy"3. Quality education says that with the child: No way. The hundred is there.

The hundred languages of the child also represent children's ability to welcome differences. What is "other", "foreign" to adults, for children is simply a horizon to be discovered, and this represents, for us, the "culture of the other".

The child, a citizen among citizens, is defined and expressed beyond traditional boundaries and ushers the way to differences.

The child is the first "stranger" among us. A stranger because they are foreign to rules and conventions, an "uncomfortable child". A stranger who reveals to us the other who is in us: we see ourselves through the gaze of the other, and by educating ourselves we educate each other to a new reality.

\section{Rights, educational poverty and crisis}

Today we are wondering how we can address the most urgent questions that challenge education. We are accompanied by an insatiable search, that "nostalgia for the future" with which Loris Malaguzzi invited us to have the courage of the future, to seek new paradigms, to welcome the unexpected and the unknown. It is a recommendation, too, not to be overwhelmed by indifference and resignation, it is a substantial confidence in the human community to walk to its own horizon and this is also the key to a common commitment.

The right begets right and women's rights begat the child's right to quality education.

2 L. Malaguzzi, A Charter of Rights, 4.

3 C. Edwards, L. Gandini, G. Forman, The hundred languages of children, 3. 
This right has not taken root autonomously in the general culture, which still considers them associated. It was not perceived as an indirect or direct right, even of the family.

The child-citizen is still a fragile subject, even though they are recognised and defined as holders of rights. In the 1970s, this awareness partly contributed to the creation of public and private spaces and environments that provided for the presence of children, such as swimming pools and playrooms in apartment buildings. So, the first neighbourhoods with spaces for children and children's libraries were created. There was a time when everyone had to participate in building paradigms for these rights.

The theme is cultural: understanding childhood as a common good.

This should therefore engage not only the public system but, for example, the manufacturing and the services industry, to help solve the problems of children's rights.

I don't know if the Coronavirus has deleted or frozen this right when the places designed to make it visible, i.e., preschools and infant-toddler centres were closed. Certainly, it has made visible that childhood, and the child in general, exists only as a subspecies of the society, as a "child", precisely as a minor, not as a citizen. Hardly anyone took care of this issue, in fact, until women took care of it and went to work.

Now children, and also women - because the regression affected also the women's rights - have been brought back into a mother-child nucleus, deleting the concept of family and extended family.

We should wonder why this society kills this childhood, its childhood, thus renouncing a quality of the present and a living dimension of the future.

By overthrowing the rights of many, as it has happened in this time, it is necessary to have a general view, and reiterate a firm point, that the significance of infant-toddler centres and preschools is to make a right and an educational, democratic, and participatory dimension true.

The necessary deployment of some summer services should not deceive us. These are reception if at all care services, especially to grant adults' work. The "micro", against which we have fought for the relationship with a large and varied community, seems acceptable to us today because it is controllable.

Let us get back around the table to ask ourselves what phenomenology has appeared and what pedagogy needs to be activated so as to renew the strength and meaning of infant-toddler centres and preschools.

The rights of children, young people, women and men, essentially of the humanity, aged 0 to 99 years, to quality education and a better life, wherever they live, while placing education as an emergency that helps in dealing with other emergencies: this is the prospect we have to set. 
The proposal for quality education can be, if not an answer, a way to confront this moral duty of tackling educational poverty.

First of all, because childhood is given the right to have rights. Rights of their own, a culture of their own, which elevates the child from being in need to a subject of rights. It allows to frame childhood not only as an age of life, but as a quality of life, of the human being, for the whole life.

Secondly, because children are in a relationship of reciprocity with the world around them. Worlds on worlds are added to children, teachers, parents: the neighbourhood, the community, the city. Circles that expand, from the child to infinity, in a covenant with adults that is a search for knowledge and shared paths to reach it, rather than a knowledge as mere transmission.

It is an ethics of coexistence, generated around this educational experience and achieved by planting seeds that generate processes, small growing plants. We need to have confidence in participating in a culture of rights and responsibility in every part of the world. Rights are never given, never acquired, but rights are generative, rights beget rights.

In a context of globalisation, advocating for a right anywhere in the world means affirming it and giving it the chance to be advocated everywhere. Rights should not only be understood as the self-affirmation of a right per se, but they encompass other meanings aimed at transforming this coexistence: choice, responsibility, sharing and therefore they refer to the "duty" meant as the complementary face of law. "The fact that the rights of children are recognized as the rights of other children is the sign of a more accomplished humanity" says Loris Malaguzzi ${ }^{4}$. A call for everyone to great responsibilities and the possibility of opening up horizons and better futures, which we have to try to build together. That "more accomplished humanity", which is an ethics of coexistence, which is respect, tolerance, care, dialogue, participation, reciprocity and solidarity among all stakeholders, each with their own culture.

\section{The educational experience of Reggio Emilia}

The educational experience of Reggio Emilia and the dialogue that the city has been able to establish with a small, but great in terms of truth and depth, part of the world taught me to look at preschools as an evidence of a new cultural and civil sensibility towards childhood in the contemporary era.

There are a lot of protagonists in this collective story - the Municipal Administration, Loris Malaguzzi, the many different people, especially women, teachers, atelieristas, cooks, mothers, female citizens - who have contributed

4 L. Malaguzzi, A Charter of Rights, 2. 
to the development of the educational system of infant-toddler centres and preschools in the city of Reggio Emilia.

Today, the experience is known throughout the world as Reggio Emilia Approach. This philosophy is based on the image of child as a subject with rights from birth, competent to learn and relate to others from birth, provided with extraordinary learning potential that is metaphorically described with the expression of "a hundred languages", namely, the hundred, thousand ways of expressing themselves, of thinking, understanding, learning, that Malaguzzi described in a poem, thus composing a true "manifesto" of the rights of children and human beings.

\section{Fondazione Reggio Children}

The essence of our Foundation is not only to improve the life of children and communities by fostering a quality education worldwide but to improve itself in this process so as to imagine, develop, concretize futures. Even if and where it seems to be difficult, almost impossible.

This is the invitation that the Foundation addresses, today like in the past, to its partners in drawing possible futures by intertwining their desires, by overcoming frustrations, by embracing concerns and doubts, as necessary.

With this attitude and this awareness Fondazione Reggio Children carries out its projects by facing new challenges and picking up further possibilities, by building up new relationships or intensifying the consolidated ones. By opening new research horizons - taste, food, nutrition - or by investigating recurring themes with new eyes: the quality of the educational contexts, the new technologies as possible tools for solidarity and alliance of the human being, the participatory dimension in socially problematic contexts, just to mention a few. Awareness that comes along with the courage of making mistakes.

Having the courage of making mistakes, of acting with generosity, of being amazed and surprised is something we learned from children and young people.

And this is the strength we would like to apply to the experiences we set up in the world so that the world doesn't lose its childhood, the significance of childhood, and therefore its own significance.

To continue to construct a different future.

The Foundation promotes research projects that define and redefine the very meaning of research.

The Foundation is like a cultural laboratory whose quality is built through the research, meant in a broader sense, which includes the academic, scientific research but it also introduces a different concept and form of research that takes place whenever original learning processes occur. 
An existential and ethical attitude that highlights - once again - the value of research but also the search for values. A research that appreciates and valorizes the diversity and the and/and approach rather than a dualistic or/or.

So, a research that doesn't exclude an investigation and a quantitative evaluation but that highlights the qualitative dimension where the meaning is not rebuilt only by looking and observing, it isn't only in the surrounding nature waiting to be revealed but it is built through the process.

Willing to look for new paradigms, embracing the unexpected and the unknown, developing transformative dialogues in new contexts because foreign, Fondazione Reggio Children promotes solidarity projects and activities, far away from welfare attitudes, but rather as a research strategy and as a dialogue mode among partners who intend to improve the life of children and communities by fostering a quality education.

\section{Conclusions}

Rights are never given, never acquired.

But rights are generative. Rights beget rights.

In a context of globalisation, advocating for a right in Reggio Emilia means affirming it and giving it the chance to be advocated everywhere. That's why we never have to take them for granted.

At the same time, if it is true that the climate emergency - which is changing the lives of millions of people, causing migration and poverty - depends on human behaviour, we can say that the most serious planetary emergency is exactly the educational one.

It is important, therefore, to continue to question ourselves how to bring rights to those who do not even know they have them, how to make our interventions lasting, how, from childhood onwards, to act in a way that makes communities strong and able to walk on their own.

Malaguzzi states: "The fact that the rights of children shall be the rights of other children is the dimension of value of a more fulfilled humanity".

A call for everyone to great responsibilities and the possibility of opening up horizons and better futures, which I ask to try to build together.

For this reason, it will be important - and this is something many people have been working on in recent years - to extend the UN Convention to the right to pre-school education, so as to allow the richness and fullness of the first season of the human being to be fully expressed.

There is an old African proverb saying "it takes a whole village to raise a child".

We are suggesting you that it takes a child, it takes childhood to improve a community, whether local or global. 
After all, many children and young people today, collectively, are asking to be listened to.

\section{NO WAY. THE HUNDRED IS THERE}

The child

is made of one hundred.

The child has

a hundred languages

a hundred hands

a hundred thoughts

a hundred ways of thinking

of playing, of speaking.

A hundred always a hundred

ways of listening

of marveling, of loving

a hundred joys

for singing and understanding

a hundred worlds

to discover

a hundred worlds

to invent

a hundred worlds

to dream.

The child has

a hundred languages

(and a hundred hundred hundred more)

but they steal ninety-nine.

The school and the culture

separate the head from the body.
They tell the child:

to think without hands

to do without head

to listen and not to speak

to understand without joy

to love and to marvel

only at Easter and at Christmas.

They tell the child:

to discover the world already there

and of the hundred

they steal ninety-nine.

They tell the child:

that work and play

reality and fantasy

science and imagination

sky and earth

reason and dream

are things

that do not belong together.

And thus they tell the child

that the hundred is not there.

The child says:

No way. The hundred is there ${ }^{5}$.

\section{Bibliography}

Acemoglu D., Robinson J. A., Why Nations Fail: the Origins of Power, Prosperity, and Poverty, New York 2012.

Arnheim R., Art and Visual Perception, Oakland 1954.

Balducci E., L'uomo planetario, Firenze 2005.

Banerjee A. V., Duflo E., Good Economics for Hard Times: Better Answers to Our Biggest Problems, New York 2019.

Banerjee A. V., Duflo E., Poor Economics, a Radical Rethinking of the Way to Fight Global Poverty, New York 2011.

Basaglia O. F. et al, Il bambino sociale. Privatizzazione e deprivatizzazione dell'infanzia, ed. E. Becchi, Milano 1979.

Bateso G., Mind and Nature, New York 1979.

5 C. Edwards, L. Gandini, G. Forman, The hundred languages of children, Praeger 2012. 
Bateson G., Steps to an Ecology of Mind, San Francisco 1972.

Bauman Z., Missing Community, Cambridge 2000.

Bauman Z., Postmodernity and its Discontents, Cambridge 1997.

Bauman Z., The Individualized Society, Cambridge 2001.

Ceppi G., Zini M., Children, Spaces, Relations. Metaproject for an Environment for Young Children, Reggio Emilia 1998.

Branzi A., La crisi della qualità, Milano 1996.

Bruner J. et al., Attraversar confini. Idee ed esperienze in dialogo per una nuova cultura dell'educazione dei bambini e degli adulti, ed. Comune di Reggio Emilia, Istituzione Scuole e Nidi d'infanzia, Reggio Children, Associazione Internazionale Amici di Reggio Children, Azzano S. Paolo 2006.

Bruner J.S., Actual Minds, Possible Worlds, Cambridge 1986.

Bruner J.S., The Culture of Education, Cambridge 1996.

Bruner J.S., The Relevance of Education, New York 1996.

Bruner J.S., Toward a Theory of Instruction, Cambridge 1974.

Cagliari P., La partecipazione. Valori, significati, problemi e strumenti, Reggio Emilia 1994.

Calvino I., Lezioni americane, Torino 1988.

Cambi F., Manuale di storia della pedagogia, Bari 2003.

Canovi A., Lorenzi O., Borghi E., Una storia presente. L'esperienza delle scuole comunali dell'infanzia a Reggio Emilia, Reggio Emilia 2020.

Castagnetti M., Rubizzi L., Vecchi V., In viaggio coi diritti delle bambine e dei bambini, Reggio Emilia 1995.

Da Empoli G., Un grande futuro dietro di noi, Venezia 1996.

Dahlberg G., Moss P., Ethics and Politics in Early Childhood Education, London 2005.

Dahlberg G., Moss P., Pence A., Beyond Quality in Early Childhood Education and Care, Languages of Evaluation, London 2007.

De Gouges O., The Declaration of the Rights of Women, London 2018.

Deaton A., The Great Escape: Health, Wealth and the Origins of Inequality, Princeton 2013.

Delrio G., Città delle persone. L'Emilia, l'Italia e una nuova idea di buon governo, Roma 2011.

Dewey J., Democracy and Education, New York 1916.

Dewey J., Experience and Education, New York 1959.

Dewey J., My Pedagogic Creed, Washington 1929.

Edwards C., Rinaldi C., The Diary of Laura. Perspectives on a Reggio Emilia Diary, St. Paul 2008.

Edwards C., Gandini L., Forman G., I cento linguaggi dei bambini, Parma, Italia 2017.

Edwards C., Gandini L., Forman G., The Hundred Languages of Children. The Reggio Emilia Approach to Early Childhood Education, Norwood, NJ 1993.

Freire P., Edução como prática da liberdade, Rio de Janeiro 1973. 
Freire P., Pedagogia do oprimido, São Paulo 1970.

Gallese V., Dai neuroni specchio alla consonanza intenzionale. Meccanismo neurofisiologici dell'intersoggettività, "Rivista di Psicoanalisi" 2007 LII.

Gandini L., Etheredge S., Hill L., Insights and Inspirations from Reggio Emilia, Worcester, MA: Davis 2009.

Gandini L., Mantovani S., Edwards C., Il nido per una cultura dell'infanzia, Azzano S. Paolo 2003.

Gardner H., Development and Education of the Mind, London 2005.

Gardner H., Five Minds for the Future, Harvard 2006.

Gardner H., Frames of Mind. The Theory of Multiple Intelligence, New York 1983.

Gardner H., The APP Generation: How Today's Youth Navigate Identity, Intimacy, and Imagination in a Digital World, New Haven 2014.

Giudici C., Vecchi V., Children, Art, Artists. The Expressive Languages of Children, the Artistic Language of Alberto Burri, Reggio Emilia 2004.

Giudici. C., Krechevsky M., Rinaldi C., Making Learning Visibile, Reggio Emilia 2001.

Giudici. C., Krechevsky M., Rinaldi C., Rendere visibile l’apprendimento, Reggio Emilia 2009.

Godbout J. T., Caillé A., The World of the Gift, tr. Donald Winkler, Montreal 1998.

Grieshaber S., Hatch J. A., Pedagogical documentation as an effect of globalization, "Journal of curriculum theorizing" 2003, 19, No. 1.

Hall E.L., Rudkin J. K., Seen and Heard. Children's Rights in Early Childhood Education, New York 2011.

Han B.-C., Saving Beauty, Cambridge 2017.

Han B.-C., The Expulsion of the Other: Society, Perception and Communication Today, Cambridge 2018.

Malaguzzi L., Loris Malaguzzi and the Schools of Reggio Emilia. A Selection of his Writings and Speeches, 1945-1993, ed. P. Cagliari, M. Castagnetti, C. Giudici, C. Rinaldi, V. Vecchi, P. Moss, London 2016.

Malaguzzi L., A Charter of Rights, Reggio Emilia: Preschools and Infant-toddler Centres Istituzione of the Municipality of Reggio Emilia, From the "The Hundred Languages of Children” exhibition catalogue, published by Reggio Children.

Mancuso V., La via della bellezza, Milano 2018.

Mantovani S., Nostalgia del futuro. Liberare speranze per una nuova cultura dell'infanzia, Bergamo 1998.

Montessori M., Educazione e pace, Milano 1949.

Montessori M., La scoperta del bambino, Milano 1950.

Morin E., Sept savoirs nécessaires à l'éducation du futur, Paris 1999.

Morin E., La tête bien faite. Repenser la réforme et Réformer la pensée, Paris 1999.

Morin E., Relier les connaissances. Le défi du XXIème siècle, Paris 1999.

Musatti T., Picchio M., Il monitoraggio della qualità dei servizi integrativi per bambini piccoli, Roma 2003. 
OECD, Education at a Glance, Paris 2019.

Piaget J., La naissance de l'intelligence chez l'enfant, Paris 1977.

Piaget J., Psychologie et épistémologie : pour une théorie de la connaissance, Paris 1970.

Piaget J., Six Etudes de psychologie, Genève 1964.

Piketty T., The Economics of Inequality, Cambridge 1997.

Putnam R. D., Making Democracy work. Civic tradition in modern Italy, NJ 1993.

Rajan R., The Third Pillar. How Markets and the State leave the Community behind, New York 2019.

Read H., Education Through Art, London 1943.

Resnick M., Lifelong Kindergarten. Cultivating Creativity through Projects, Passion, Peers, and Play, Cambridge 2017.

Rifkin J., The Empathic Civilisation, New York 2010.

Rinaldi C., I processi di conoscenza dei bambini tra soggettività ed intersoggettività, Reggio Emilia 1999.

Rinaldi C., L'ascolto visibile, Reggio Emilia 1999

Rinaldi C., Le domande dell'educare oggi, Reggio Emilia 1999.

Rinaldi C., In Dialogue with Reggio Emilia. Listening, Researching and Learning, New York 2006.

Rodari G., The Grammar of Fantasy: An Introduction to the Art of Inventing Stories, New York 1996.

Rousseau J. J., Emile, Paris 1969.

Scuola di Barbiana. Lettera a una professoressa, Firenze 1967.

Sen A. K., Development as Freedomm New York 1999.

Sen A. K., La ricchezza della ragione, ed. A. Balestrino, B. Ingrao, G. M. Mazzanti, Bologna 2011.

Sennett R., Together. The Rituals, Pleasures and Politics of Cooperation, New Haven 2012.

Steffe L.P., Gale E. J., Constructivism in Education, Hillsdale, NJ 1995.

Stieglitz J. E., Globalization and its Discontent, New York 2002.

UNICEF. A World Ready to Learn: Prioritizing Quality Early Childhood Education, New York 2019.

Vygotsky L. S., Thought and Language, Cambridge 1986.

Vygotsky L. S., The History of the Development of Higher Mental Functions (Vol. 4 The Collected Works of L.S. Vygotsky), New York 1997.

Yunus M., A World of Three Zeros: the New Economics of Zero Poverty, Zero Unemployment, and Zero Net Carbon Emissions, New York 2017.

Žižek S., Welcome to Interesting Times!, London 2011. 


\section{SUMMARY}

The child as citizen: holder of rights and competent. The Reggio Emilia educational experience

The postulate, the reference value, from which the experience of the infant-toddler centres and preschools in Reggio Emilia and Fondazione Reggio Children draw inspiration, considers the child a citizen from birth and competent to learn and love and are capable of building relationships with the world. By affirming the right to be recognised as a citizen of the present, competent, culture-generating, we affirm on the one hand the strength and extraordinary potential of each child and their right to express them, and at the same time the duty of societies and communities to welcome them, supporting their learning processes and embracing their creativity and uniqueness. In this perspective, infant-toddler centres and preschools are the educational places par excellence, where to build an experience of care and community for the child as a citizen. They are not unique spaces of education, but essential places because this is where children's culture, their gaze towards the world, their generative questions, the hundred languages, with which they learn and narrate the world, are generated and shaped. For a quality education based on this rationale, it is necessary to put children and young people, their relationships with their family and community at the centre, and for this to happen, listening is essential. It is necessary to know how to listen to them, with respect, without prejudice, acknowledging their points of view, experiences, hypotheses, and knowledge. The pedagogy of listening has not only to do with school, it has to do with our humanity, all the more so in the time of epidemics and major climate change. It concerns us as human beings not "in front of", but inside the universe. Before our birth, we live for nine months inside a body that we listen to and that listens to us: surrounded by dialogue, listening becomes an innate, natural attitude. This attitude must be confirmed, backed, supported in all environments of human life, starting from school. 